\title{
中國科學院院務常務會議關於金屬 研究工作報告㱫工作的决議
}

\section{（一）1954年10月29日第38次院務常務會議决議}

逜次金屬㸴究工作報告會的內容涉及範圍頗

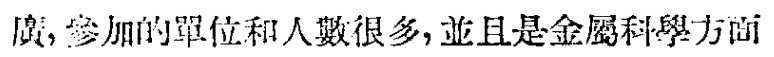

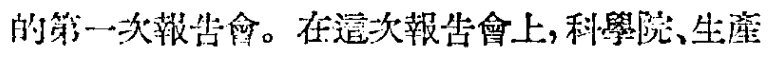
部F䅀、滈等學校的科學工作者將相互交流砳究工。

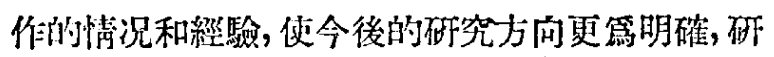
究工作更加與生隺實際密切聯系。這次報告會將 對我國當前的工業建設起重要的作詡。院敄常弱

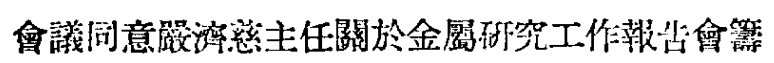

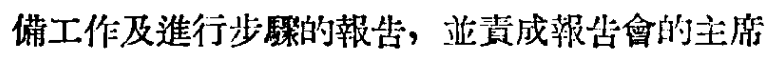
團在會議進行中注意下列幾點:

1. 每一專業小組應對每一報告詳加討諭, 亚

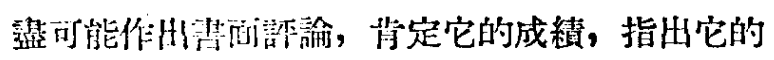

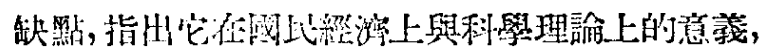
並捉出它在蛽绦工作中推废的可能性。專業小組 並應顕小組卻論中的重大問題作出击泊結諭。
2. 主席團應對報告會上的主要砳究工作成

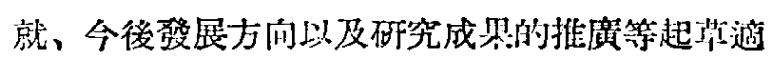

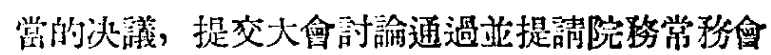
㼁批准，使之成篇全體金屬科學工作者必須共阔 逶守的原则。

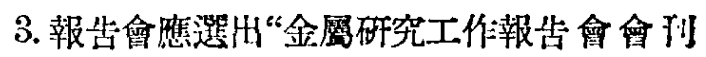

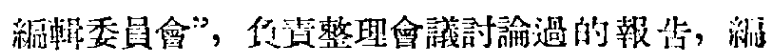

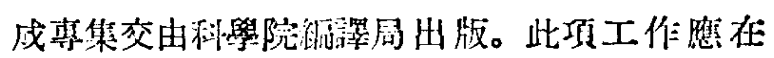
1955年 6 月底以前完成。

4. 篇促進各有閣方面在金屬湖究工作上的密

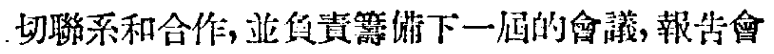

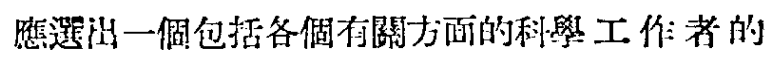
“金屬研究工作協調委員會”以進行上逃工作。咕 调委員會的工作必須隨狩與各方面的專家取得箈 切聯系。

\section{（二）1954年11月25日第41次院務常務㬝議决議}

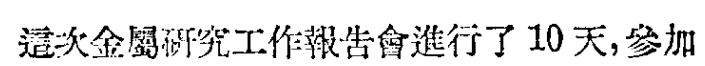

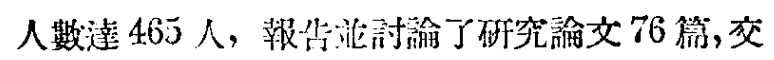

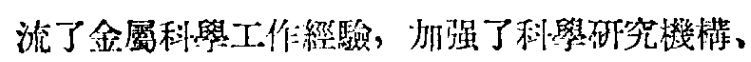

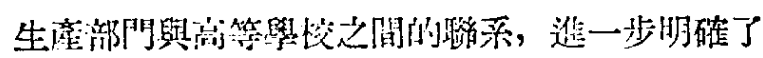

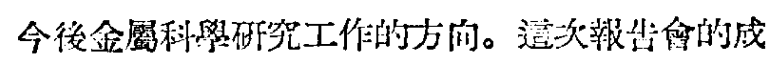

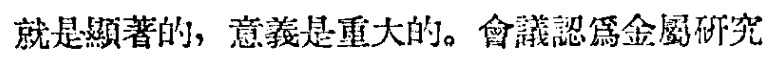

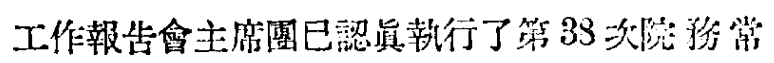
務會議閵於金屬研究工作報告會進行工作的冯 紋。

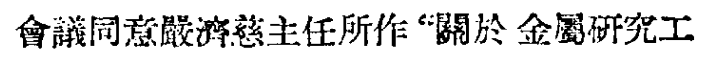
作報告會的工作赫皆", 亚批准金屬研究工作報告
會所通過的决議及“金屬研究工作協調委員會”具

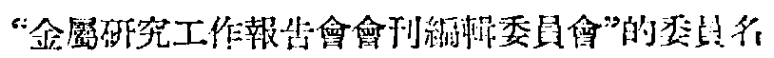

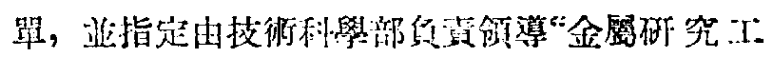

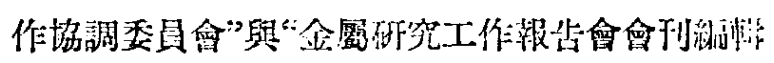

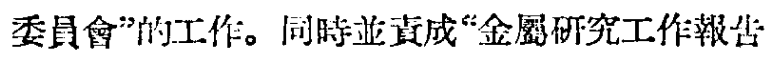

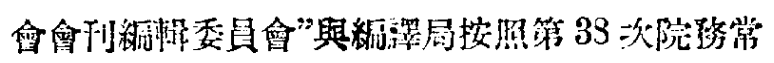

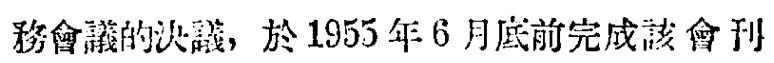
的细㛫出版东宜。

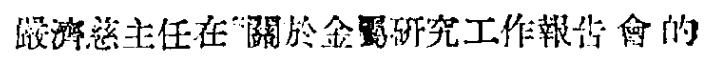

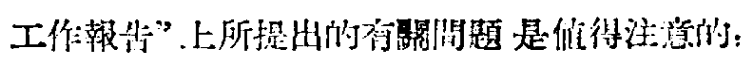
會詳認䉆: 
1. 金属研究工作報告會决議中建議推廣的若 千研究成果, 應由院向座業部門提出具體建議;

2. 金屈研究工作報告會决議中指出的若干研 究工作基本方向，虑第本院所属的冶金潄究單位 所通循了

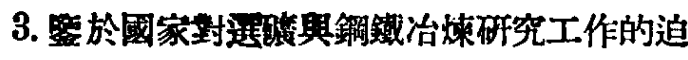

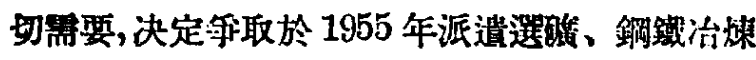
二個筫習小組边蘇繁替;

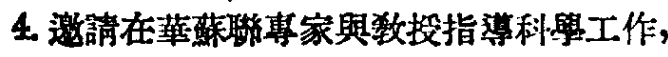

對推動我國科學事業的㗶展是有重要意義的，資

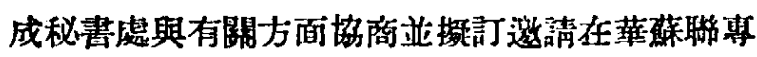
家與敉授參加本院工作的方案;

5. 本院有關國際科學技街合作事宜日谷增

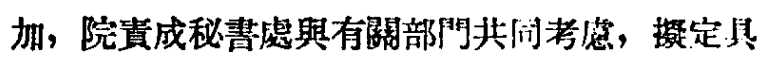
體處理本院有關國際科學技術合作的辦法。

會議决定將金屬研究工作報告會的主要結果 向國務院提出書面報告，並指定由技術科部合 同秘觜處負資起草。 